\title{
PENERAPAN MODEL ROLE PLAYING BERBANTUAN MEDIA KOMIK UNTUK MENINGKATKAN HASIL BELAJAR BAHASA INDONESIA PADA PESERTA DIDIK KELAS V SDN-1 TELANGKAH TAHUN PELAJARAN 2016/2017
}

\author{
Oleh: Agustin Dwi Utami, Dedy Setyawan, M.Pd
}

\begin{abstract}
ABSTRAK
Penelitian ini bertujuan untuk mendeskripsikan aktivitas peserta didik kelas $\mathrm{V}$ SDN-1 Telangkah dalam pembelajaran Bahasa Indonesia dengan menggunakan model role playing berbantuan media komik serta meningkatkan hasil belajar Bahasa Indonesia peserta didik kelas V SDN-1 Telangkah dengan menggunakan model role playing berbantuan dengan media komik peserta didik kelas V SDN-1 Telangkah. Metode yang digunakan peneliti adalah Penelitian Tindakan Kelas (PTK) dengan subjek penelitian 31 peserta didik yang terdiri dari 12 laki-laki dan 19 perempuan kelas V SDN-1 Telangkah. Teknik pengumpulan data dalam penelitian ini menggunakan observasi dan tes. Analisis data menggunakan analisis data kualitatif dan kuantitatif. Hasil penelitian ini menunjukkan bahwa aktivitas peserta didik kelas V SDN-1 Telangkah pada saat pembelajaran berlangsung dengan menggunakan model role playing berbantuan media komik pada mata pelajaran Bahasa Indonesia tentang materi Memerankan Drama pada siklus I sudah dalam kategori sangat baik. Selain itu ada peningkatan hasil belajar Bahasa Indonesia dengan menerapkan model role playing berbantuan media komik pada peserta didik kelas V SDN-1 Telangkah. Hal ini terlihat dari data hasil belajar peserta didik, pada pre test rata-rata nilai 61 dengan ketuntasan klasikal 45,16\%, sedangkan hasil post test siklus I rata-rata nilai 78 dan ketuntasan secara klasikal yaitu $100 \%$.
\end{abstract}

Kata Kunci: Model Role Playing, media komik, aktivitas peserta didik, hasil belajar Bahasa Indonesia.

\begin{abstract}
This study aims to describe the activities of fifth-grade students of SDN Telangkah-1 in learning the Indonesian language by using role-playing models assisted by comic media as well as improving Indonesian language learning outcomes of fifth-grade students of SDN-1 Telangkah by using role-playing models supported by humorous media participants fifth-grade students of SDN-1 Telangkah. The method used by the researcher was Classroom Action Research (CAR) with research subjects 31 students consisting of 12 men and 19 female class V SDN-1 Telangkah. Data collection techniques in this study used observation and tests. Data analysis uses qualitative and quantitative data analysis. The results of this study indicate that the activities of fifth-grade students of SDN1 Telangkah at the time of learning took place by using a role-playing model assisted by comic media on Indonesian language subjects about material Playing the Drama in the first cycle was in an outstanding category. Also, there was an increase in the results of learning the Indonesian Language by applying the role-
\end{abstract}


playing model assisted by comic media to the fifth-grade students of SDN-1 Telangkah. This can be seen from the learning outcomes data of students, in the pre-test, the average score of 61 with classical completeness was $45.16 \%$, while the post-test results in the first cycle the average rating of 78 and integrity in the traditional, i.e. $100 \%$.

\section{Keywords: Role Playing Model, comic media, student activities, Indonesian} language learning outcomes.

\section{PENDAHULUAN}

Sebagian orang menganggap belajar Bahasa Indonesia adalah hal yang mudah akan tetapi ternyata pernyataan ini sangat berbanding terbalik dengan kenyataan yanga ada, faktanya masih banyak peserta didik bosan dengan pelajaran Bahasa Indonesia dan mereka di saat proses pembelajaran ada yang ngantuk dan ngobrol dengan teman sebangkunya, sehingga berdampak pada hasil belajaranya kurang.

Penerapan model pembelajaran Role Playing atau bermain peranadalah sejenis permainan gerak yang di dalamnya ada tujuan, aturan, dan edutainment Fogg (Huda 2013: 208) peserta didik dikondisikan pada situasi tertentu diluar kelas, meskipun saat itu pembelajaran terjadi di dalam kelas. Selain itu, Role Playing sering kali dimaksudkan sebagai suatu bentuk aktivitas di mana pembelajaran membayangkan dirinya seolah-olah berada diluar kelas dan memainkan peran orang lain.

Komik juga dapat dijadikan media pembelajaran. Gambar dalam komik biasanya berbentuk atau berkarakter gambar kartun. Ia mempunyai sifat yang sederhana dalam penyajiannya, dan memiliki unsur urutan cerita yang memuat pesan yang besar tetapi disajikan secara ringkas dan mudah dicerna, terlebih lagi ia dilengkapi dengan bahasa verbal yang dialogis. Dengan adanya perpaduan antara bahasa verbal dan nonverbal ini, mempercepat pembaca paham terhadap isi pesan dimaksud, karena pembaca terbantu untuk tetap fokus dan tetap dalam jalur. Peranan pokok dari buku komik dalam pengajaran adalah kemampuannya dalam menciptakan minat para peserta didik.

Alasan menggunakan model Role Playing ini yaitu bertujuan untuk membantu peserta didik mengeksplorasi perasaan dan keterampilan untuk memeran kan sebuah peran agar mudah memahami materi pelajaran dengan cara berbeda. Media komik dipilih karena, media komik mampu menyajikan gambar cerita secara konkret dengan ilustrasi gambar dan dialogmembuat ceritanya menjadi ringkas dan menarik perhatian.

Berdasarkan hasil observasi yang dilakukan pada peserta didik kelas $\mathrm{V}$ di SDN-1 Telangkah bahwa dalam kegiatan pembelajaran Bahasa Indonesia interaksi antara guru dengan peserta didik kurang aktif. 
Hal ini dikarenakan peserta didik kurang memahami materi yang dijelaskan oleh guru, ini disebabkan karena model yang kurang bervariasi membuat peserta didik kurang bersemangat dalam belajar sehingga minat peserta didik untuk belajar sangat rendah, sehingga menimbulkan masalah rendahnya hasil belajar Bahasa Indonesia. Karena berdasarkan informasi yang didapat dari guru mata pelajaran Bahasa Indonesia kelas V SDN-1 Telangkah bahwa Kriteria Ketuntasan Minimal (KKM) pada mata pelajaran Bahasa Indonesia yaitu 65, dibuktikan dengan hasil belajar Bahasa Indonesia peserta didik pada kelas $\mathrm{V}$ yang berjumlah 31 orang. Peserta didik mendapatkan nilai diatas 65 hanya berjumlah 12 orang berarti 19 orang peserta didik belum mencapai kriteria ketuntasan minimal.

Hasil wawancara diketahui bahwa faktor penyebab rendahnya hasil belajar Bahasa Indonesia dikarenakan faktor dari peserta didik itu sendiri dan faktor dari guru. Faktor dari peserta didik adalah perhatian peserta didik terhadappelajaran masih kurang, kesulitan dalam memahami materi. Sedangkan faktor dari guru penyebabnya ialah guru tidak menerapkan model pembelajaran yang bervariasi. Dalam pembelajaran cenderung menggunakan model yang kurang bervariasi, sehingga peserta didik kurang memperhatikan pembelajaran.
Untuk itu seharusnya guru menerapkan model pembelajaran yang dapat membuat interaksi antara peserta didik dengan guru menjadi aktif, yang akan menunjang proses pembelajaran sehingga tujuan pembelajran dapat tercapai secara maksimal dengan demikian hasil belajar peserta didik dapat meningkat menjadi lebih baik.

Diharapkan dengan menerapkan model Role Playing berbantuan dengan media komik ini hasil belajar akan optimal. Hal ini dikarenakan peserta didik memperoleh pengalaman belajar disekolah dengan kehidupan nyata. Sehingga materi yang dipelajari langsung dengan melakukan percobaan dan pengamatan akan tertanam kuat dalam memori peserta didik, sehingga pelajaran yang diberikan guru tidak akan mudah lupa.

Berdasarkan permasalahan yang ditemukan, maka peneliti tertarik untuk melakukan penelitian mengenai penerapan model pembelajaran Role Playing berbantuan media komik untuk meningkatkan hasil belajar Bahasa Indonesia peserta didik kelas $\mathrm{V}$ SDN-1 Telangkah.

Berdasarkan permasalahan diatas maka peneliti tertarik untuk melakukan penelitian yang berjudul "Penerapan Model Role Playing Berbantuan Media Komik Untuk Meningkatkan Hasil Belajar Bahasa Indonesi Pada Peserta Didik Kelas V SDN-1 TelangkahTahun Pelajaran 2016/2017" 


\section{METODE PENELITIAN}

Penelitian ini menggunakan rancangan Penelitian Tindakan Kelas (PTK) yang dikategorikan penelitian yang berusaha untuk memecahkan atau menjawab permasalahan yang dihadapi pada situasi tertentu. Masalah PTK harus berasal dari guru itu sendiri yang berkeinginan memperbaiki mutu pembelajaranya di sekolah dalam rangka meningkatkan mutu pendidikan.

Menurut Car dan Kemmis (Kusumah 2012: 8) adalah suatu "bentuk penelitian yang refleksi diri (selfreflective )yang dilakukan oleh parapartisipan dalam situasi sosial untuk memperbaiki rasionalitas dan kebenaran".

Menurut Arikunto (Taniredja 2013: 15) penelitian tindakan kelas merupakan suatu:

pencermatan terhadap kegiatan belajar berupa sebuah tindakan, yang sengaja dimunculkan dan terjadi dalam sebuah kelas secara bersama. Tindakan tersebut diberikan oleh guru atau dengan arahan dari guru yang dilakukan oleh peserta didik.

Dari penjelasan - penjelasan diatas maka dapat disimpulkan bahwa PTK (Penelitian Tindakan Kelas) adalah suatu tindakan yang dilakukan pendidik / peneliti untuk memecahkan berbagai masalah mengenai proses pembelajaran, dimaksudkan untuk melakukan perbaikan-perbaikan terhadap sistem, isi dan kompetensi atau situasi pembelajaran dengan menguji cobakan suatu ide ke dalam situasi nyata dalam proses pembelajaran di kelas dengan harapan kegiatan tersebut dapat meningkatkan hasil belajar peserta didik.

Kehadiran peneliti sangat diperlukan setiap kegiatan ditempat penelitian karena peneliti berperan sebagai perencana, pelaksanaan tindakan, pengamat, pengumpul dan penganalisis data serta sebagai pelapor hasil penelitian.

Peneliti juga bekerjasama dengan guru kelas atau teman sejawat untuk berperan sebagai pengamat (observer) yang bertugas mengumpulkan data ketika proses pembelajaran berlangsung dengan menggunakan lembar pedoman pengamatan yang telah disediakan oleh peneliti.

Pada penelitian ini data yang diperoleh dari penelitian dianalisis dengan menggunakan teknik analisis data kualitatif dan kuantitatif. Kualitatif akan mendeskripsikan hasil penelitian dan Kuantitatif yang akan menyajikan hasil penelitian berupa angka. Adapun instrumen penelitian yang digunakan pada penelitian ini adalah observasi dan tes. Observasi adalah suatu teknik pengamatan yang dilakukan secara langsung atau tidak langsung dan secara teliti terhadap suatu gejaladalam suatu situati di suatu tempat. Observasi dilakukan oleh 2 orang observer yaitu 1 orang mahasiswa dan 1 orang guru dengan mengisi lembar pengamatan yang tersedia. Menurut Riyadi (Mahmud, 2011: 185) menyatakan bahwa, "tes 
kemampuan hasil belajar atau tes prestasi belajar adalah tes untuk mengukur kemampuan yang dicapai seorang setelah melakukan proses belajar".

\section{HASIL DAN PEMBAHASAN}

Beradasarkan hasil analisis data di atas dapat di simpulkan bahwa keterampilan berbicara bermain peran dalam pelajaran Bahasa Indonesia peserta didik kelas $\mathrm{V}$ dengan penggunaan model pembelajaran role playing yang berbantuan media komik, mengalamai peningkatan dari 31 peserta didik terdapat 31 peserta didik yang memperoleh nilai lebih dari 65 dengan rata-rata 78 dan presentasi data ketuntasan $100 \%$. Hal tersebut telah meningkat, dibandingkan dengat data awal yang hanya memperoleh nilai rata-rata 61 dengan presentasi data ketuntasan klasikal 45,16\%.

Berdasarkan hipotesis tindakan yang telah ditetapkan dalam bab sebelumnya, maka hipotesis tindakan tersebut akan teruji kebenarannya, adalah sebagai berikut:

1. Aktivitas peserta didik pada pembelajaran Bahasa Indonesia kelas $\mathrm{V}$ SDN-1 Telangkah dengan menggunakan model pembelajaran Role Playing berbantuan media komik menjadi sangat baik.

Dalam pengujian hipotesis tindakan terhadap aktivitas belajar peserta didik digunakan mengetahui kebenaran dalam peningkatan aktivitas belajar peserta didik.
Berdasarkna hasil pengamatan dan data yang diperoleh pada siklu I, aktivitas peserta didik memperoleh skor rata-rata 3,79 dengan kriteria sangat baik. Hal ini telah menunjukan bahwa peserta didik kelas V SDN-1 Telangkah aktif saat pembelajaran Bahasa Indonesia dengan menerapkan model pembelaran role playing berbantuan media komik pada materi memerankan drama, maka hipotesis teruji kebenarannya.

Berikut tabel data peningkatan aktivitas guru dan peserta didik saat proses belajar mengajar :

Data Pengamatan Aktivitas Guru dan Peserta Didik

\begin{tabular}{|c|c|c|}
\hline \multirow{2}{*}{ No } & \multicolumn{2}{|c|}{ Aktivitas } \\
\cline { 2 - 3 } & Guru & Peserta Didik \\
\hline 1. & 3,79 & 3,79 \\
\hline
\end{tabular}

2. Ada peningkatan hasil belajar Bahasa Indonesia pada peserta didik kelas V SDN-1 Telangkah dengan menggunakan model pembelajaran Role Playing berbantuan media komik.

Berdasarkan hasil tes dan data yang diperoleh data pre test, hasil belajar peserta didik memperoleh nilai rata-rata 61 (KKM 65) dengan ketuntasan klasikal 45,16\%. Pada Siklus I hasil peserta didik memperoleh nilai rata-rata 78 dengan ketuntasan klasikal 100\%. Hal tersebut telah mencapai indikator keberhasilan penelitian yang telah ditetapkan yaitu hasil belajar peserta didik mencapai KKM 65 dengan ketuntasan klasikal $85 \%$. Sehingga dapat disimpulkan 
bahwa ada peningkatan hasil belajar Bahasa Indonesia peserta didik kelas $\mathrm{V}$ dengan menerapkan model role playing berbantuan media komik,maka hipotesis tindakan teruji kebenarannya.

Berikut data peningkatan hasil belajar peserta didik dari pra tindakan (tes awal) ke siklus I berdasarkan nilai rata-rata peserta didik dan persentase ketuntasan klasikal :

\section{KESIMPULAN}

1. Aktivitas belajar peserta didik dalam pembelajaran Bahasa Indonesia dengan menerapkan model pembelajaran role playing berbantuan mediakomik pada kelas V SDN-1 Telangkah Tahun Pelajaran 2016/2017, menjadi baikhal tersebut dilihat dari aktivitas peserta didik merespon terhadap kegiatan pembelajaran dalam melaksanakan tugas yang diberikan guru yaitu dengan menceritakan pengalaman secara lisan, dengan skor rata-rata 3,79 kriteria sangat baik.

2. Ada peningkatan hasil belajar Bahasa Indonesia dengan menerapkan model pembelajaran role playing berbantuan media komik pada kelas V SDN-1 Telangkah Tahun Pelajaran 2016/2017. Hal ini dapat diketahui pada tahap awal dengan nilai rata-rata yaitu 61 dengan ketuntasan klasikal 45,16\%, mengalami peningkatan pada siklus I yakni mencapai rata-rata
78 dengan ketuntasan klasikal $100 \%$.

\section{DAFTAR PUSTAKA}

Taniredja, dkk. (2013). Penelitian tindakan kelas untuk meningkatkan profesi guru. Bandung: CV Alvabet.

Huda, Miftahul. (2013). ModelModel Pengajaran dan Pembelajaran. Yogyakarta: Pustaka Pelajar.

Kusumah, Wijaya. \& Dwitagama, Dedi. (2012). Mengenal penelitian tindakan kelas. Jakarta: PT Indeks. 